\title{
Pengaruh Video Lagu Anak - Anak Terhadap Pemerolehan Bahasa Anak Usia Dini (Kajian Psikolinguistik) Early Child Language Acquisition and The Impact of Children's Songs Video (Psycolinguistics Studies)
}

Fienny Maria Langi ${ }^{1)}$ Mariana Lusye Marlyn Lausan ${ }^{2)}$ Margaritha Narahawarin ${ }^{3)}$ Eightmarc Louis Johanes Pinontoan ${ }^{4}$

Institut Agama Kristen Negeri Manado; Universitas Musamus Merauke; Universitas Bina Nusantara fiennylangi@iakn-manado.ac.id ${ }^{l)}$ marianalausan@iakn-manado.ac.id ${ }^{2}$ naraharawin_fkip@unmus.ac.id ${ }^{3}$ johanespinontoan22@gmail.com ${ }^{4)}$

\begin{abstract}
Abstrak
Pemerolehan Bahasa pada anak - anak tidak akan berlangsung dengan baik apabila tidak disertai dengan stimulus dari lingkungan sekitarnya. Penelitian ini dilakukan untuk mendeskripsikan pengaruh video lagu anak - anak sebagai salah satu stimulus terhadap pemerolehan Bahasa anak usia dini. Metode yang digunakan dalam penelitian ini ialah kualitatif deskriptif, dengan pemaparan situasi yang disajikan dalam bentuk uraian naratif. Subjek penelitian adalah anak usia dini yang sedang berada dalam fase sintaksis. Berdasarkan hasil penelitian, dapat disimpulkan bahwa video lagu anak - anak memiliki pengaruh yang signifikan pada pemerolehan Bahasa anak. Banyaknya perbendaharaan kata dalam video menjadi stimulus yang tepat bagi anak usia dini untuk mengembangkan proses pemerolehan Bahasa.
\end{abstract}

Kata Kunci : Pemerolehan Bahasa, anak usia dini, psikolinguistik.

\section{Abstract}

Language acquisition in children will not work well without the stimulus from the surrounding environment. This study was designed to describe the influence of children's song video as one of the stimulus to early childhood language acquisition. The method used in this study is descriptive qualitative, with the exposure of situations presented in narrative form. The subject of this study is an early child who is in the syntactic phase. Based on the results, it can be concluded that children's song video has a significant impact on children's language acquisition. The abundance of vocabulary in the video has been the right stimulus for early teens to develop the language acquisition process.

Kata Kunci : language acquisition, early childhood, psycholinguistic.

\section{PENDAHULUAN}

Bahasa merupakan sarana komunikasi utama dalam kehidupan manusia, baik dalam bentuk tulisan, lisan, maupun dalam bentuk symbol - symbol tertentu. Tanpa bahasa, manusia tidak dapat berkomunikasi secara tepat, karena manusia adalah mahkluk sosial yang harus berinteraksi dengan sesama manusia. Dalam interaksi, terjadi proses komunikasi, dan proses komunikasi tersebut menggunakan bahasa sebagai alat untuk menyampaikan tujuan. Bahasa manusia diperoleh sejak dalam kandungan. 
Pembelajaran bahasa berkaitan dengan proses - proses yang terjadi pada fase awal manusia, yaitu pada waktu seorang kanak - kanak mempelajari bahasa kedua, sesudah ia belajar bahasa pertamanya.

Dalam prosesnya, pengembangan berbahasa memiliki empat komponen yang terdiri dari pemahaman, pengembangan perbendaharaan kata, penyusunan kata - kata menjadi ucapan, dan penyusunan ucapan menjadi kata - kata dan kalimat. Empat struktur ini memiliki hubungan yang saling terkait satu dengan yang lain, dan merupakan suatu kesatuan yang perlu dilatih pada anak usia dini. Seperti yang kita ketahui, kemampuan berbahasa pada anak usia dini adalah kunci bagaimana anak bisa berkomunikasi dengan orang lain, sehingga anak mampu untuk menyampaikan apa yang diinginkannya secara tepat.

Hal ini sesuai dengan apa yang diungkapkan dalam kurikulum 2004, yaitu bahwa kompetensi dasar dari pengembangan bahasa untuk anak usia dini dilihat dari kemampuan anak untuk bisa mendengar, berkomunikasi secara lisan, memiliki perbendaharaan kata yang cukup, serta mampu mengenal simbol - simbol dan pelambangannya. Anak dalam proses perkembangan pada usia dini cenderung menggunakan bentuk - bentuk bahasa yang mampu diucapkannya, sehingga orang tua dan lingkungan sekitar anak harus berusaha memahami maksud akan tuturan anak tersebut.

Belajar bahasa merupakan proses pembentukan kebiasaan yang dihasilkan dari input dalam penguatan mental yang diterima anak. Anak sebagai peniru ulung cenderung mencontoh apa yang dilihat dan diamatinya sehari - hari. Kegiatan stimulus pembelajaran bahasa, bisa berupa penguatan positif dari kebiasaan berbahasa yang benar, ataupun penguatan negatif dari kebiasaan berbahasa yang salah. Ilmu tentang menganalisis bahasa sebagai bagian dari sikap mental masuk dalam kajian Psikolinguistuk.

Psikolinguistik adalah sebuah ilmu gabungan antara dua ilmu, yaitu ilmu Psikologi dan Linguistik. Dardjowidjoyo mendefinisikan Psikolinguistik sebagai ilmu yang mempelajari proses - proses mental yang dilalui oleh manusia dalam mereka berbahasa. Secara rinci, psikolinguistik mempelajari empat topik utama, yaitu (a) Komprehensi, yang adalah proses-proses mental yang dilalui oleh manusia sehingga mereka dapat menangkap apa yang dikatakan orang dan memahami apa yang dimaksud, (b) Produksi, yaitu proses - proses mental pada diri kita yang membuat kita dapat berujar seperti yang kita ujarkan, (c) Landasan Neurologis dan Biologis yang membuat manusia bisa berbahasa, dan (d) Pemerolehan Bahasa, yakni bagaimana seseorang memperoleh Bahasa mereka. (Darwiwidjoyo, 2016, p.7)

Pemerolehan bahasa, atau disebut juga dengan language acquisition adalah proses pada otak manusia disaat seseorang menerima dan memperoleh Bahasa pertamanya dalam hal ini dikenal dengan Bahasa ibu. Kridalaksana mengatakan bahwa pemerolehan Bahasa adalah proses pemahaman dan penghasilan Bahasa pada manusia melalui beberapa tahap, mulai dari meraban sampai kefasihan penuh. (Kridalaksana, 2013) Pemerolehan Bahasa itu sendiri berbeda dengan pembelajaran Bahasa. Pemerolehan Bahasa mengacu kepada bagaimana seseorang menguasai Bahasa ibu, sedangkan pembelajaran Bahasa berkaitan dengan proses mempelajari dan menguasai Bahasa kedua. Proses pemerolehan Bahasa terbagi dalam dua bagian besar, yaitu proses kompetensi dan proses performasi. Kompetensi adalah proses penguasaan Bahasa yang berlangsung secara otomatis dan tanpa disadari, sedangkan performasi adalah proses yang terjadi sesudah proses kompetensi dikuasai. 
Pemerolehan bahasa anak dibagi menjadi beberapa tataran kebahasaan, yaitu 1) Fase Fonologis (0-2 tahun), pada tahap ini anak bermain dengan bunyi-bunyi bahasa dan mulai mengoceh sampai menyebutkan kata-kata sederhana 2) Fase Sintaksis (2-7 tahun), pada tahap ini anak menunjukkan kesadaran gramatis dan berbicara menggunakan kalimat 3) Fase Semantik (7-11 tahun), pada tahap ini anak dapat membedakan kata sebagai simbol dan konsep yang terkandung dalam kata. (Zuchdi dan Budiash dalam Nuryani, 2013, hlm. 107)

Ada empat tahap pemerolehan bahasa, yang dilihat dari ilmu psikolinguistik, yaitu 1) tahap pralinguistik (0-12 bulan) bayi sudah bisa menggeram dan menghasilkan banyak suara 2) tahap satu-kata (12-18 bulan) ditandai dengan anak yang sudah belajar menggunakan satu kata yang mewakili idenya, pada tahap ini orang tua atau orang lain juga perlu memperhatikan aktivitas anak dan unsur-unsur nonlinguistik lainnya seperti gerak, isyarat, ekspresi, dan benda yang ditunjuk oleh anak. 3) tahap dua-kata (18-24 bulan) ditandai dengan anak yang sudah mengombinasikan dua kata dalam bentuk ucapan pendek tanpa kata depan, kata tunjuk dan bentuk lainnya, 4) tahap banyak kata (3-5 tahun) ditandai dengan kemampuan seorang anak membuat kalimat pertanyaan negatif, kalimat majemuk dan berbagai bentuk kalimat. Pada usia 3-4 tahun tuturan anak mulai panjang dan tata bahasanya teratur. (Ingram, 2013, pp.91-94)

Pemerolehan Bahasa pada anak selalu melewati proses yang sama. Dimulai dengan cooing (mendekut) pada umur 6-8 minggu, yakni mengeluarkan bunyi bunyian yang menyerupai bunyi vocal dan konsonan. Bunyi - bunyian ini belum dapat diidentifikasi sebagai bentuk kata, tetapi sudah dikategorikan sebagai bunyi. Selanjutnya tahapan babbling (celoteh) pada sekitar umur 6 bulan, yakni mengeluarkan bunyi yang berupa suku kata. Pada umur sekitar 1 tahun, anak mulai mengeluarkan bunyi yang dapat diidentifikasi sebagai kata. Untuk jenis Bahasa yang kebanyakan monomorfemik (bersukukata satu), maka suku itu atau sebagian dari suku kata tersebut mulai diujarkan. Untuk Bahasa yang kebanyakan polimorfemik, maka suku akhirlah yang diucapkan, dan belum tentu lengkap. Kemudian anak akan mulai berujar dengan ujaran satu kata (One Word Utterence), lalu menjelang umur 2 tahun dimulai dengan ujaran dua kata (Two Word Utterence). Terakhir pada sekitar umur 4 - 5 tahun, anak akan lebih mampu untuk dapat berkomunikasi dengan lancar. (Darwowidjoyo, 2016, p.198)

Tahapan perkembangan berbicara pada anak yang normal dikenali dengan 1) usia 12-15 bulan; kalimat belum jelas, dia mulai mengucapkan beberapa patah kata tapi tidak jelas 2) usia 16-17 bulan; anak sudah dapat menguasai 7-20 kata termasuk kata yang baru di dapatnya 3) usia 18 bulan; anak sudah dapat merangkai dua kata menjadi kalimat sederhana 4) usia 21-30 bulan; anak sudah mencapai lebih dari 50 kata 5) usia 36 bulan, anak sudah bisa menguasai 250 kata dan membentuk kalimat yang terdiri dari tiga kata. (Subyantoro, 2013) Pemerolehan Bahasa sendiri berlangsung secara alamiah pada tahap mendengar dan menyimak.

Pemerolehan Bahasa terjadi pada usia awal anak, dimana anak biasanya membutuhkan pendampingan dan stimulus yang tepat dari lingkungan sekitarnya, untuk bisa menunjang proses tersebut berjalan dengan baik. Seorang bayi yang baru belajar berbicara hanya akan merespon ujaran - ujaran yang sering didengarnya dari lingkungan sekitar. Demikian juga dengan anak usia dini, yang berada dalam fase Fonologis dan fase sintaksis pada proses pemerolehan Bahasa.

Anak Usia Dini adalah sekelompok anak dengan rentang umur $0-6$ tahun. Sebagaimana di kemukakan oleh Khadijah bahwa anak usia dini ialah anak yang 
berumur $0-6$ yang memiliki proses perkembangan dan pertumbuhan yang lebih pesat dan fundamental pada awal - awal tahun kehidupannya. (Khadijah, 2016, p.11)Anak usia dini disebut sedang berada pada masa keemasannya (Golden Age) karena mereka mampu menyerap informasi serta stimulus yang diberikan dengan cepat.

Kegiatan dan stimulasi yang tepat akan mampu meningkatkan perkembangan berbahasa pada anak, khususnya balita. Salah satu kegiatan dalam proses pemerolehan Bahasa pada anak usia dini adalah dengan mendengarkan lagu. Kegiatan mendengarkan lagu dan bernyanyi sangat melekat erat dan tidak bisa dipisahkan dari kehidupan anak anak. Farida, dkk berpendapat bahwa mendengarkan adalah suatu proses menangkap, memahami, dan mengingat dengan sebaik-baiknya apa yang didengarnya atau sesuatu yang dikatakan orang lain kepadanya. (Ariani et al, 2009)

Anak usia dini cenderung menyukai cerita atau lagu yang memiliki frasa berulang, karena hal tersebut membuatnya merasa terlibat. Lagu anak - anak memiliki diksi yang jelas, dan mempunyai lirik yang berulang, sehingga memudahkan anak untuk mengahafal pemenggalan kata pada lirik lagu.

Penelitian tentang pemerolehan Bahasa pada anak - anak sudah banyak dilakukan. Beberapa penelitian sebelumnya seperti yang dilakukan oleh Rerin Maulinda tentang Pemerolehan Bahasa Pertama Pada Anak Usia 0 - 3 Tahun (Tinjauan Psikolinguistik), yang menemukan adanya kesamaan dalam setiap tahap pemerolehan bahasa, yaitu adanya proses fonologi, morfologi, sintaksis, semantik, dan pragmatik. Mulia Kurniati dan Nuryani juga melakukan penelitian serupa tentang Pengaruh Sosial Media Youtube Terhadap Pemerolehan Bahasa Anak Usia 3 - 4 Tahun (Studi Pada Anak Speech Delay), yang menemukan bahwa media YouTube memiliki pengaruh yang signifikan terhadap pemerolehan Bahasa anak usia $3-4$ tahun, terlebih khusus anak yang memiliki ganggguan keterlambatan bicara.

Sejauh ini, penelitian tentang pengaruh video lagu anak - anak terhadap pemerolehan Bahasa anak usia dini belum banyak dilakukan. Karena ini, tulisan ini diharapkan mampu menambah referansi dalam dunia kajian Psikolinguistik, sehingga memicu penelitian - penelitan yang lebih relevan.

\section{Metode}

Jenis penelitian ini adalah penelitian deskriptif kualitatif. Penelitian deskriptif kualitatif merupakan penelitian yang mencoba memberi gambaran secara sistematis tentang situasi, permasalahan, fenomena, layanan atau program yang menyediakan informasi. Data yang diperoleh dalam penelitian ini, dituangkan dalam bentuk narasi, dan tidak berupa angka - angka. Penelitian ini bertujuan mendeskripsikan secara terperinci tentang pemerolehan Bahasa anak dalam kehidupan sehari-hari yang distimulus oleh video lagu anak - anak.

Subjek penelitian dalam tulisan ini adalah seorang anak bernama $\mathrm{C}$ berumur 29 bulan, yang tidak memiliki gangguan keterlambatan bicara atau keterbatasan fisik lainnya. Objek kajian dalam penelitian ini adalah pengaruh video lagu anak - anak terhadap proses pemerolehan Bahasa subjek C.

Tahap Pengumpulan data dilakukan dengan cara 1) memberikan sebuah tontonan audio-visual berupa video lagu anak - anak dalam media sosial YouTube, channel BabyBus dan CocoMelon, 2) merekam tanggapan narasumber 3) membuat transkip tanggapan narasumber 4) meneliti hasil transkip dengan teori pemerolehan bahasa 5) memberi kesimpulan mengenai pengaruh video lagu anak - anak terhadap pemerolehan Bahasa anak usia dini. 


\section{Hasil dan Pembahasan}

Narasumber $\mathrm{C}$ adalah seorang anak yang aktif dan responsif terhadap hal - hal baru. C yang berumur 29 bulan berada dalam fase Sintaksis dalam pemerolehan Bahasa, dengan pemerolehan kata lebih dari 50 kata, sesuai dengan tahapan perkembangan bicara.

Peneliti memberikan tontonan video lagu anak - anak dalam media sosial YouTube, khususnya channel BabyBus dan CocoMelon. Lagu - lagu yang ditayangkan memiliki diksi, frase yang jelas serta disajikan dengan singkat, sehingga menarik bagi C. Saat diminta untuk bernyanyi bersama, $\mathrm{C}$ mengiyakan dan berjanji akan bernyanyi bersama - sama .

Peristiwa tutur yang adalah tanggapan narasumber saat peneliti menunjukkan video lagu anak - anak direkam dalam transkripsi fonetis.

Ket. C : Narasumber

P : Peneliti

LVA : Lagu video anak

Peristiwa tutur 1 (Video lagu anak-anak dengan judul : "Cuci Tangan Sebelum Makan", dipasang untuk ketiga kalinya)

LVA : "ayo kita makan, makan, makan." (video menunjukkan gambar makanan)

C : "bakan, bakan."

LVA : "Ayo! Ayo! Ayo!"

$\mathrm{C}:$ : "ayo, ayo, ayo"

LVA : "cuci tangan dulu, agar tidak ada kuman"

C : "tuman, kotol"

LVA : "tangan harus bersih sebelum makan"

C : "tuti tangan duyu"

LVA : "jangan lupa pakai sabun, agar tidak ada kuman"

C : "kuman abis"

LVA : "ayo cuci tangan."

C : "ayo, ayo."

$\mathrm{P}$ : "wah, hebat sekali ade so tau. Ayo cuci tangan"

C : "ayo, ayo."

(Video selesai diputar)

Peristiwa tutur 2 (Video lagu anak-anak dengan judul: "Sakit Perut", dipasang kedua kalinya)

LVA : "kemarin aku makan es krim dengan banyak"

$\mathrm{C}:$ : "e klim"

$\mathrm{P} \quad$ : "Ade suka makan es krim?"

C : "iya, cuka."

LVA : "terlalu banyak sampai sakit perut"

C : "cakit pelut dia"

LVA : "aku harus ke rumah sakit untuk periksa"

C : "ambuwans, ngiung-ngiung-ngiung" (video menunjukkan gambar mobil ambulans datang menjemput anak yang sakit)

$\mathrm{P} \quad$ : "ade suka naik ambulans?"

C : " "ndak mau. Ade nda cakit." (Video selesai diputar). 
Peristiwa tutur 3 (Video lagu anak-anak dengan judul : "Mobil warna - warni”, dipasang untuk kedua kalinya)

LVA : "ini mobil - mobilan punyaku.." (video menunjukkan gambar mobilmobilan)

$\mathrm{C} \quad$ : (masih menonton, dan belum merespon)

P : "waah..., ada banyak mobil."

LVA : "ada bermacam-macam, mobil dan warnanya."

C : "wow, manyak"

LVA : "mobil pemadam kebakaran berwarna merah

C : "kalan, melah"

LVA : "mobil polisi berwarna biru"

C : "ici, bilu"

LVA : "mobil ambulans berwarna putih"

C : "buwan, puti"

$\mathrm{P} \quad$ : "ade suka warna apa?"

C : "ade cuka bilu, putih, kalan"

(Video selesai diputar)

Peristiwa tutur 4 (Video lagu anak-anak dengan judul : "Twinkle - twinkle little star", dipasang untuk ketiga kalinya)

LVA : "Twinkle - twinkle little star," (video menunjukkan gambar bintang bintang)

C : "tal"

LVA : "how I wonder what you are."

C : "al"

$\mathrm{P}$ : "bintang - bintang"

LVA : "up above the world so high."

C : "ay"

LVA : "like a diamond in the sky" (video kembali menunjukkan gambar bintang)

C : "tay"

(video selesai diputar)

Dari transkripsi data penelitian, diketahui bahwa narasumber menunjukkan ketertarikan terhadap video lagu anak - anak yang diputar oleh peneliti. C yang berusia 29 bulan sedang berada dalam fase sintaksis dimana terjadi pembentukan banyak kata, dan hal ini ditandai dengan kesadaran gramatis dan berbicara dengan menggunakan kalimat. Pada masa ini, stimulus dan pendampingan yang tepat, perlu dilakukan.

Pada transkrip peristiwa tutur 1, C mencoba menggandakan atau meniru dan mengucapkan kembali kata terakhir yang didengarnya dalam lagu, walaupun $\mathrm{C}$ belum bisa mengucapkan keseluruhan kata dengan jelas. Saat video lagu diputar untuk pertama kalinya, C belum mencoba mengikuti kalimat - kalimat yang ada dalam lagu, walaupun dia sudah menunjukkan ketertarikan terhadap video tersebut. Saat $\mathrm{C}$ menonton video itu untuk ketiga kalinya, barulah $\mathrm{C}$ mengikuti beberapa kata yang sempat diingatnya.

Pada usia 2 dan 3 tahun, anak mulai menghasilkan ujaran kata-ganda (multipleword utterances) atau disebut juga ujaran telegrafis. Anak juga sudah mampu membentuk kalimat dan mengurutkan bentuk-bentuk itu dengan benar. Kosakata anak 
berkembang dengan pesat mencapai beratus-ratus kata dan cara pengucapan kata-kata semakin mirip dengan Bahasa orang dewasa. Pada usia dini dan seterusnya, seorang anak belajar Bahasa ibu secara bertahap dengan caranya sendiri. Ada teori yang mengatakan bahwa seorang anak dari usia dini belajar bahasa dengan cara menirukan. Namun, hasil peniruan yang dilakukan oleh si anak tidak akan sama seperti yang diinginkan oleh orang dewasa.

Sama seperti subjek $\mathrm{C}$ yang dalam penelitian ini beraksi terhadap video lagu anak - anak yang diperlihatkan kepadanya. $\mathrm{C}$ menirukan beberapa kata pada video, namun dengan beberapa kesalahan penyebutan fonem. Fonem-fonem seperti /c/, /l/, /k/ dan /s/, /t/ cenderung lesap, seperti pada kata yang seharusnya "es" dilafalkan dengan "e'. Terdapat pelesapan fonem /s, dan pengulangan fonem /p/ dan /o/. C melafalkan fonem $/ \mathrm{s} /$ dengan fonem $/ \mathrm{t} /$, fonem $/ \mathrm{r} /$ dilafalkan dengan fonem $/ \mathrm{l} /$, /s/ dilafalkan dengan fonem /dz/ dan fonem /1/ kadang dilafalkan dengan fonem /y/ dalam kata 'gula'. Dalam kata sakit, fonem /s/ dilafalkan dengan fonem /dz/.

Peristiwa tutur 2 menunjukkan bahwa subjek $\mathrm{C}$ belum bisa melafalkan fonem /s/ dan /r/ dengan tepat. Pada kata 'es krim', terjadi pelesapan pada fonem /s/, sehingga kata 'es' hanya dibunyikan 'e'. untuk fonem /r/ pada kata 'krim' juga dilafalkan dengan fonem /1/, sehingga kata 'krim' berubah menjadi 'klim'. Saat peneliti mencoba berkomunikasi dan bertanya kepada subjek, subjek merespon dengan menjawab pertanyaan peneliti. Hanya saja, jawaban yang diberikan subjek juga masih berupa kata dengan fonem yang tidak tepat. Peneliti bertanya apakah subjek suka makan es krim, dan subjek menjawab 'suka', tetapi subjek mengganti fonem /s/ pada kata 'suka' dengan fonem /c/, sehingga dibunyikan 'cuka'. Demikian juga pada kata 'sakit', subjek C mengganti fonem /s/ dengan fonem /c/, sehingga menjadi kata 'cakit'. Untuk kata 'anbulans', subjek melakukan pelesapan terhadap fonem /1/, dan merubah dengan fonem /w/ menjadi 'ambuwans'. Selanjutnya pada kata 'sakit', subjek mengganti fonem /s/ dengan fonem /c/, sehingga kata 'sakit' berubah menjadi 'cakit'.

Pada peristiwa tutur yang ketiga, peneliti menunjukkan video dengan gambar mobil berwarna - warni, dengan memutarkan video berulang kali (dua kali). Saat pertama kali ditunjukkan, subjek $\mathrm{C}$ belum menunjukkan respon terhadap video yang dipasang. Saat peneliti memberikan penguatan berupa pujian dan kekaguman terhadap mobil dalam video. Sesudah mendengar penguatan yang diberikan peneliti, subjek $\mathrm{C}$ mulai merespon dengan berkata 'manyak', yang berarti 'banyak' walaupun mengganti fonem $/ \mathrm{b} /$ dengan fonem $/ \mathrm{m} /$. Saat video menunjukkan gambar mobil kebarakan, C bereaksi dengan menirukan apa yang diucapkan oleh suara di video, seperti kata 'kebakaran' dan kata 'merah', yang berubah menjadi kata 'melah' dengan perubahan fonem /r/ menjadi /1/, dan kata 'kebakaran' dengan pelesapan dua suku kata pertama.

Selanjutnya subjek C kembali menunjukkan reaksi saat lagu video anak - anak menunjukkan adegan mobil polisi yang berwarna biru. Gambar pada layar dengan diiringi lagu yang mengucapkan kata mobil polisi berwarna biru, kembali menarik perhatian subjek, sehingga subjek terdorong untuk mengucapkan kata yang diucapkan pada video, yaitu kata 'polisi' dan kata 'biru'. Dalam pelafalannya, subjek melesapkan suku kata pertama untuk kata 'polisi' sehingga menjadi 'ici', dan menggunakan fonem /1/ sebagai pengganti untuk fonem /r/ pada kara biru. Untuk kata 'ambulans', subjek melesapkan suku kata pertama dan mengubah fonem /r/ menjadi /w/, sehingga diucapkan sebagai 'buwan'. Untuk kata 'putih' yang menunjukkan warna, subjek mengucapkan secara tepat berdasarkan pelafalan bahasa Melayu Manado, yang sering melesapkan fonem $/ \mathrm{h} /$ pada akhir kata. 
Peneliti kemudian memberikan pertanyaan secara acak kepada subjek, dengan bertanya tentang warna kesukaan subjek. Walaupun belum mengerti akan pertanyaan peneliti, subjek tetap menjawab dengan mengatakan bahwa subjek menyukai warna biru, putih dan kebarakan. Subjek sendiri belum memahami bahwa kata 'kebakaran' tidak termasuk dalam kelompok warna. Pada kejadian ini, dapat dilihat bahwa subjek tidak ragu untuk berkomunikasi dengan orang lain, dengan kepercayaan diri subjek dalam membalas pertanyaan yang diberikan oleh peneliti. Subjek yang mendengar katakata dalam video, merasa yakin akan penguasaan perbendaharaan yang dimiliki, sehingga subjek mampu menjawab pertanyaan yang didengarnya dari peneliti.

Hal seperti ini adalah salah satu bentuk komunikasi anak dengan orang lain. Walaupun anak belum memahami makna sintaksis yang sesungguhnya, tetapi saat anak mampu menunjukkan keberanian dalam berkomunikasi, sudah merupakan salah satu bentuk perkembangan dalam proses pembelajaran bahasa bagi anak usia dini.

Sesuai dengan teori yang mengatakan bahwa seorang anak belajar dengan cara penguatan (reinforcement) (Chaer, 2009), dalam peningkatan pemerolehan bahasanya, subjek $\mathrm{C}$ mendapat penguatan dalam bentuk pujian, misalnya hebat, bagus, pintar, dan sebagainya, yang dalam penelitian ini dilakukan oleh peneliti sebagai bentuk pendampingan belajar. Disaat $\mathrm{C}$ melakukan reduplikasi terhadap kata dan kalimat yang didengarnya, peneliti mememberikan penguatan berupa pujian. Hal ini membangkitkan rasa percaya diri $\mathrm{C}$, sehingga dia berani untuk menambah lagi ujaran - ujaran seperti yang didengarnya di video lagu anak - anak.

Selama proses ini, peneliti tidak memberikan penguatan negatif apabila anak tidak merespon atau mengucapkan kata dengan tidak tepat. Peneliti justru memutar kembali video sampai beberapa kali, seperti yang terjadi dalam peristiwa tutur 2, dimana C sama sekali tidak merespon saat video dipasang untuk pertama kalinya. Setelah video dipasang untuk kedua kalinya, respon yang diberikan $\mathrm{C}$ tidak dengan mereduplikasi lirik lagu, melainkan dengan menyebutkan gambar - gambar yang dilihatnya seperti es krim, serta menirukan bunyi sirene mobil ambulans. Subjek C juga menunjukkan pemahaman akan fungsi mobil ambulans, dilihat dari tanggapannya atas pertanyaan peneliti, apakah $\mathrm{C}$ suka naik mobil ambulans. Dari jawabannya, diketahui bahwa $\mathrm{C}$ mengerti fungsi mobil ambulans adalah untuk orang sakit, dan $\mathrm{C}$ tidak mau menjadi orang sakit dengan naik mobil ambulans.

Pada peristiwa tutur tiga, $\mathrm{C}$ bukan saja mereduplikasi kata - kata yang didengar, tetapi juga menunjukkan pemahaman terhadap warna dan gambar yang dilihat. Saat peneliti memberikan stimulus dengan menunjukkan banyak mobil, subjek $\mathrm{C}$ mereduplikasi kata 'banyak' dengan 'manyak', kemudian menirukan kata - kata sesuai lirik lagu. Dapat dilihat bahwa C mulai mengingat beberapa kosakata yang baru saja didengarnya dalam video tersebut, walaupun $\mathrm{C}$ belum sepenuhnya mengerti maksud tuturan yang diucapkan. Hal ini ditunjukkan $\mathrm{C}$ dalam menjawab pertanyaan peneliti tentang warna kesukaan. C menjawab 'bilu, putih, dan kalan' yang berarti 'biru, putih, dan mobil pemadam kebakaran'. $\mathrm{C}$ tidak mengerti bahwa mobil pemadam kebakaran tidak termasuk dalam golongan warna, tetapi $\mathrm{C}$ sudah berani mencoba mengucapkan kosakata untuk mobil pemadam kebakaran.

Selanjutnya dalam transkripsi pada peristiwa tutur 4, ditunjukkan bahwa subjek C melakukan reduplikasi kata [star] dengan tuturan [tal], [are] dengan dituturkan [al], dan [sky] dengan [tay]. Video keempat adalah video berbahasa Inggris, yang bukan menjadi bahasa ibu subjek C. Tetapi, subjek ternyata mampu melakukan proses reduplikasi pada beberapa morfem, walaupun dengan kelemahan dan kekurangan dalam proses 
fonologinya. Pada morfem [star], fonem /st/ mengalami pelesapan sehingga yang terdengar hanyalah bunyi [tal]. Morfem [are] mengalami perubahan pada fonem $/ \mathrm{r} /$ digantikan dengan fonem /l/, sedangkan pada morfem [high] terjadi pelesapan untuk fonem /h/ juga /I/, menjadikan morfem [high] berubah menjadi [ay]. Demikian juga dengan morfem [sky] yang mengalami perubahan pada fonem /s/ dan pelesapan pada fonem $/ \mathrm{k} /$, digantikan dengan fonem /t/ sehingga tercipta morfem [tay] dan bukan [sky].

Kejadian pada peristiwa tutur 4 menunjukkan bahwa jenis bahasa bukanlah penghalang anak untuk belajar berbahasa. Anak tetap menunjukkan usaha untuk melafalkan beberapa kata yang arti dari kata itu sendiri belum tentu dipahami oleh sang anak. Proses ini tentunya dapat dimanfaatkan oleh orang tua dalam pembelajaran bahasa asing lainnya sebagai bahasa kedua.

Reduplikasi yang terjadi pada sujek $\mathrm{C}$ disebabkan oleh stimulus dari video yang lagu anak - anak yang dipasang berulang - ulang. Kata - kata yang didengar oleh subjek, membekas pada ingatan subjek, sehingga subjek merasa terdorong untuk mengucapkan kata - kata yang didengarnya berkali - kali. Dalam peristiwa ini, subjek sendiri belum sepenuhnya memahami arti kata yang diucapkannya, tetapi subjek tetap mencoba melafalkan kata tersebut. Tidak ada rasa malu dan subjek menunjukkan rasa percaya diri yang tinggi dalam proses reduplikasi yang dilakukan, walaupun masih ada kesalahan gramatikal dalam pelafalan dan bunyi kata.

Dalam kegiatan ini, peneliti berimprovisasi terhadap pandangan yang mengatakan bahwa apabila ucapan, tuturan, dan bahasa yang digunakan seorang anak salah, maka harus segera diperbaiki, dan memuji apabila ujaran seorang anak itu benar. Bagi beberapa ahli psikologi dan ahli psikolinguistik, teori ini belum dapat diterima sepenuhnya, karena mereka berpendapat bahwa seorang anak membentuk aturan aturannya sendiri dalam menyusun tata bahasa.

Hal ini sesuai dengan yang ditemukan peneliti di lapangan, bahwa subjek menggunakan aturannya sendiri dalam membentuk kosakata dalam tata bahasanya sendiri. Tetapi perlu diingat, bahwa tidak semua anak akan menunjukkan kemajuankemajuan yang sama meskipun semuanya mampu menunjukkan kemajuan - kemajuan yang reguler. Ada beberapa proses dasar yang dibutuhkan anak, untuk meningkatkan kemampuan berbahasanya. Proses dsasar ini dipengaruhi oleh lingkunan, stimulus yang didapatkan, juga faktor usia. Ketrampilan - ketrampilan berbahasa lainnya juga akan berkembang seiiring dengan bertambahnya usia anak.

\section{Kesimpulan}

Akvitas yang dilakukan lewat mendengarkan lagu dan bernyanyi, mampu meningkatkan perbendaharaan kata, rasa percaya diri, serta keberanian mengambil resiko dalam pengucapan suku kata. Lagu anak - anak yang diulang-ulang akan melekat pada memori anak, sehingga mampu meningkatkan proses pemerolehan Bahasa saat anak berupaya menirukan ucapan dalam setiap lirik lagu.

Banyaknya kosakata dalam video lagu anak - anak, terbukti mampu membantu proses pemerolehan Bahasa bagi anak usia dini. Dengan menirukan dan mengucapkan kata - kata pada video lagu yang ditonton, anak menambah perbendaharaan kata bagi dirinya sendiri dan memberi pengaruh positif dalam pemerolehan Bahasa anak. Stimus postif dari video lagu anak - anak mampu meningkatan kemampuan menyimak dan kesadaran berkomunikasi anak usia dini.

Akan tetapi, kemampuan anak dalam mengucapkan kata - kata dengan jelas selalu dipengaruhi oleh kemampuan biologis, khususnya fenomena biologi perkembangan. 
Manusia tidak dapat mempercepat atau memperlambat suatu elemen Bahasa, karena hal tersebut adalah faktor genetik. Faktor lingkungan memang penting, tetapi hal tersebut hanya memicu apa yang sudah ada pada biologis manusia.

\section{DAFTAR PUSTAKA}

Chaer, Abdul. 2009. Psikolinguistik : Kajian Teori. Jakarta : PT. Rineka Cipta.

Darwowodjoyo, Soenjono. 2016. Psikolinguistik. Jakarta : Yayasan Pustaka Obor Indonesia.

Farida Ariami, Slamet Mulyana, dan Asem. 2009. Pelajaran Mendengarkan. Jakarta : Pusat Pengembangan dan Pemberdayaan Pendidikan dan Tenaga Kependidikan Bahasa.

Kridalaksana, Harimurti. 2003. Kamus Linguistik. Jakarta : PT. Gramedia Pustaka Utama.

Nuryani dan Dona Aji K.P. 2016. Psikolinguistik. Ciputau : Mazhab.

Subyantoro. 2013. Gangguan Berbahasa. Yogyakarta : Penerbit Ombak.

Khadijah. 2016. Perkembangan Kognitif Anak Usia Dini. Medan : Perdana Publishing. 